\title{
Manipulating Tradition: The State, ADAT, POPULAR PROTEST, AND CLASS CONFLICT IN COLONIAL LAMPUNG
}

\author{
Jeffrey B. Kingston
}

Throughout the colonized world, colonial administrators sought to articulate their policies in the idiom of indigenous traditions and institutions. This process of manipulating tradition to serve the interests of the state was designed to gain legitimacy among the colonized and to enable small numbers of colonizers to augment and project their limited power more effectively. As Dutch colonial rule spread through Sumatra in the nineteenth century, administrators encountered a complex system of institutions, customs, and laws known as adat. This article elucidates the processes and consequences of this encounter in Lampung, a region at the southern tip of Sumatra that was finally brought under colonial rule in 1856 after nearly a half-century of intermittent campaigns.

The Lampung case is particularly interesting because in the late 1920 s a popular political movement known as the Comite Tani Lampung led protests against the establishment of a new administrative system; the Dutch unveiled this new administrative system as a reflection of indigenous adat, whereas protestors suggested that it was a distorted version of adat at odds with the indigenous community's interests. The manipulated tradition was exposed as such and protests focused on class connotations; the Dutchified adat system and its leaders were viewed as feudal remnants blocking the path to progress. By examining the processes and implications of nurturing a hybrid tradition, the means and impact of colonial rule come into sharper focus, providing insights on the role of adat in mediating the forces of change and conflict.

\section{Deconstructing "Tradition"}

In Minangkabau historiography, an active discussion of the impact of colonialism on adat and indigenous institutions carries telling insights for understanding Lampung's expe-

Material for this article is drawn from Jeffrey B. Kingston, "The Manipulation of Tradition in Java's Shadow: Transmigration, Decentralization and the Ethical Policy in Colonial Lampung," (Ph.D. diss., Columbia University, 1987). A Fulbright-Hays doctoral research grant and subsequent funding from the Japan Society for the 
rience. Understanding how adat came to shape and be shaped by the colonial situation involves deconstructing adat and penetrating the ideology of colonial officials and contemporary social scientists concerned with elements of persistence and change in indigenous tradition and customs. ${ }^{1}$ Essentially, many adat scholars have erred in attempting to reconstruct what adat was really like in precolonial times by revealing the "true" adat based on sources treating adat after the penetration of Dutch colonialism. By following a false historical baseline, these authors present oversimplified and misleading representations of adat and its role as a source and framework for social change.

The watershed problem assumes timelessness before a selected point in time, in effect representing adat as previously static and dynamic change as occurring only thereafter. Whether it be Schrieke looking to the imposition of taxes and penetration of the money economy in the early twentieth century or Kato and Von Benda Beckmann focusing on the Cultivation System as the critical juncture, all have paid insufficient attention to the internal dynamics of change within traditional society before the cataclysm and, in so doing, have been unable to understand the impact of colonialism and the processes of historical transformations. It is not good enough to push back the date of the watershed farther and farther into history or by inference, "the end point of a static and historyless 'traditional' society," because the implied assumption, the existence of the "kernel of tradition" at some point in the historical baseline, is unsatisfactory and an unfruitful line of inquiry that bypasses the fundamental dynamism of adat as an all-encompassing, malleable embodiment of society and its historical experiences.

By basing the picture of traditional society on research conducted after the establishment of colonial rule,

The picture presented is in fact of Minangkabau society as it was under the system of forced cultivation imposed by the colonial government in the nineteenth century. Second, I suggest that the role of adat in economic and political organization extant in that period was a direct result of the imposition of colonial rule through officials such as the panghulu. ... In other words the unique political position of these officials, which stemmed from their role in the administration of colonial rule was the result of their class position, rigidified by colonial rule. ${ }^{3}$ [Emphasis added]

A more dynamic analysis of adat must address the dialectic between indigenous society and the colonial administration and the selective changes that ensued.

"Official" adat was not only shaped by "indigenous" adat, but also shaped both indigenous notions of adat and the whole organization of Indonesian society. It did this by ossifying indigenous legal systems, but also by removing them from their social context, and, often, by elevating what may have been rather unimportant features to a place of much greater significance, or even by creating essentially non-indigenous institutions

Promotion of Science are gratefully acknowledged. My thanks to those who have offered criticism, inspiration, and assistance.

1 This perspective is articulated by Joel Kahn, "Tradition, Matriliny and Change among the Minangkabau of Indonesia," Bijdragen tot de Taal-, Land-en Volken Kunde van Nederlandsch-Indië (hereafter cited as BKI) 132 (1): 6395. See also idem, review of Franz von Benda-Beckmann, Property in Social Continuity; Continuity and Change in the Maintenance of Property Relationships Through Time in Minangkabau, Verhandeling van de Koninklijke Instituut (hereafter cited as VKI), no. 86, in Indonesia Circle 22 (June 1980): 81-88; idem, review of Tsuyoshi Kato, Matriliny and Migration: Evolving Minangkabau Traditions in Indonesia, in Indonesia Circle 29 (November 1982): 50-54.

2 Kahn, review of Von Benda-Beckmann, Property in Social Continuity, p. 82.

3 Ibid., p. 80. 
and regulations which then became incorporated within indigenous ideology and social organization. ${ }^{4}$ [Emphasis added]

Thus there is the danger that the traditional society or adat institutions and relations gleaned from the archives or secondary literature is more a reflection of the colonial situation than of indigenous social organization. Although the concern of Minangkabau specialists revolves around the evolving state of matrilineal organization, many of the questions raised regarding the state's role in constructing and manipulating tradition and the manner in which the resulting hybrid constructs are insinuated into indigenous ideology animate my discussion of adat scholarship and colonial policy in Lampung.

Raymond Williams has also contributed to the deconstruction of tradition, noting how conscious policies of emphasis, selection, and exclusion operate to create a hybrid tradition that serves the interests of the dominant class in society. Although his focus is on literature and contemporary society, his theoretical discussions are relevant to the way the Dutch manipulated tradition to their own ends in Lampung. Commenting on the reinterpretation, dilution, and conversion of tradition, Williams suggests that what is posited as tradition is more usefully understood as "an aspect of contemporary social and cultural organization in the interest of a specific class. It is a version of the past which is intended to connect with and modify the present ... a deliberately selective and connecting process which offers a historical and cultural ratification of a contemporary order. ${ }^{5}$

\section{Dualism in Colonial Lampung}

The issues of time, change and persistence, selection and ratification, and ideology and historical sources raised by Kahn and Williams are crucial in understanding the anti-marga campaign waged in Lampung during the late 1920s and early 1930s. For the Dutch administration, widespread resistance to the recreation of the marga came as an unwelcome surprise because they had carefully studied Lampung's adat system and, in their view, essentially resurrected an administrative system that had prevailed in Lampung before its abolition by colonial authorities in the midnineteenth century. Moreover, there was substantial evidence that even during the period when the Dutch had not officially recognized the marga system, it had persisted unofficially among the people, and, therefore, the recognition of the pasirah (marga leader) in 1928 returned power to what the Dutch now recognized as the legitimate leaders.

The ideology of dualism, resting on the assumption of complementary Dutch and indigenous systems of government administration and justice, led colonial officials to conceptualize an untainted traditional sector, unaffected by colonial policies, a "kernel of tradition" that could serve as the basis for decentralization. The precolonial social formation expressed through adat persisted in its essential elements and, as such, could be used as the basis for promoting self-government. Such at least is evident in the writings of Van Royen, the noted adat scholar on Palembang and Lampung who participated in reestablishing the marga system in Lampung.

Van Royen's work illuminates how strongly the ideology of dualism had taken root among the colonial administrators and the degree to which it influenced their policy initiatives. In two publications on Lampung adat, Van Royen carefully details the specifics of adat law in practice, its regional variation, the influence of Bantamese suzerainty in the

4 Ibid., p. 82.

${ }^{5}$ Raymond Williams, Marxism and Literature, (London: Oxford University Press, 1977) p. 116. 
precolo nial period and the subsequent changes carried out during colonial rule before 1879.6 It is a richly detailed portrayal of a dynamic system in constant flux. Van Royen's watershed is 1879 , the year that the government introduced a Western-based administrative and legal system, and, thereafter, adat appears to lose its inherent dynamism. This initiative fostered the rise of a dualistic system in Lampung for the people continued to adhere to their adat precepts monitored by traditional leaders while complying with the new set of Western laws and institutions. ${ }^{7}$

Given his appreciation for the dynamism of adat until 1879, it is somewhat surprising that Van Royen concludes that the true adat system was able to persist intact and generally unchanged precisely because it was not recognized by the Dutch after 1879 . He argues that by introducing a Western legal and administrative system with defined areas of competence and responsibility the indigenous adat institutions, leaders, and social relations were provided a niche within which to develop and persist. "Instead of channeling adat to government ends the true adat system functioned on the side without any intrusion." 8 Indeed, the marga continued to function as distinct genealogical units with specific territorial divisions during the hiatus of official recognition unsullied by direct government manipulation. ${ }^{9}$ In his view, traditional authorities were left to their own devices by default, at least in the areas that were not of pressing concern to the Dutch.

Focusing on aspects of persistence, Van Royen noted that the marga were generally still genealogically based and that the prerogatives and responsibilities of the adat leaders continued to be recognized by the people and were ignored at their own risk. ${ }^{10}$ From the turn of the century, reports poured in about the persistence of adat-based justice, monetary levies and fines, ritual ceremonies, festivals, and so forth, indicating that the people relied, as always, on their own system for their own affairs. ${ }^{11}$ This perception set off a series of investigations into the role of adat in local affairs that culminated in the resurrection of the marga system in 1928 not as something new but as affirmation of that which was customary.

It is well to bear in mind that the policies enacted in Lampung were not formulated in a vacuum and were clearly influenced by the wider rip tide of social forces and antagonisms buffeting the colonial administration. The government chose the vernacular of tradition for its administrative reforms in the late 1920 s as a carefully gauged response to the heightened tempo of politicization (pergerakan) sweeping the Indonesian archipelago in the 1910s and 1920s. Dutch officials had come to realize that the reforms of the Ethical Policy had opened a Pandora's box and were desperately seeking ways to reseal it with stepped-up surveillance and police activities and the reemphasis of "traditional" authority.

\footnotetext{
${ }^{6}$ J. W. Van Royen, "De Verdwijning Der Lampoengsche Mergas 1855-1913," Koloniaal Tijdschrift 31 (1932): 171200; "Nota over de Lampoengsche Merga's," Mededeelingen van de Afdeeling Bestuurszaken der Buitengewesten van het Departement van Binnenlandsch Bestuur, ser. B, no. 7 (Weltevreden: Landsdrukkerij, 1930).

${ }^{7}$ B. J. Haga, "Influence of the Western Administration on the Native Community in the Outer Provinces," in The Effect of Western Influence on Native Civilizations in the Malay Archipelago, ed. B. J. O. Schrieke (Batavia: G. Kolff, 1929), pp. 171-203. Haga argues that dualism arose when government-sponsored administrative and juridical institutions were not accepted by the people.

${ }^{8}$ Van Royen, Verdwijning, p. 199. This view of persistence in adat despite enormous evident change was earlier articulated in R. Broersma, De Lampongsche Districten, (Batavia: Javasche Boekhandel en Drukkerij, 1914), p. 47.

9 Van Royen, Nota, pp. 39, 48-50.

10 Ibid., pp. 54-55.

11 Ibid., p. 55.
} 
The particular form that self-government assumed in Lampung was influenced by the adat law school led by Van Vollenhoven, who identified rapid Westernization as the source of political agitation and instability. He favored nurturing stable adat communities as a means of helping Indonesians cope with the churning changes and challenges generated by rapid socioeconomic transformations. ${ }^{12}$ The revival of the marga system in Lampung was a response to the Communist uprisings in 1926 elsewhere in Indonesia and the further disquieting surge in nationalism. In creating stable adat communities based on a co-opted and selected tradition, the Dutch hoped to undermine anticolonial agitation by harnessing the people's presumed subservience to tradition and diminishing national consciousness by reemphasizing regional differences.

Aside from these wider political considerations, the new marga system reflected ongoing Dutch efforts to promote government efficiency through administrative decentralization. In 1918, the Department of Interior Administration led an inquiry that determined that the reports from local controleurs regarding the persistence of traditional mechanisms of government and justice actually understated the high level of influence enjoyed by penjimbang (village-level adat leaders) and seriously began to entertain thoughts of restoring official recognition and power to them as a means to combat the chronic inefficiency plaguing local government and the system of governing through village heads and district demang initiated in the midnineteenth century. ${ }^{13}$ As an initial step in this direction, the government recognized a number of district proatin (tribunals for adjudication of adat disputes), and clearly there was an impetus toward greater reliance by the Dutch on adat institutions that was consistent with both perceptions of prevailing practice and the dilatory moves toward decentralization launched in 1903 in Java.

As it became increasingly apparent that the Dutch aims were not being fulfilled by the incumbent administrative system, reports about the vibrance of the alternative system, the other half of the dual administrative structure, captured the imagination of a new wave of colonial administrators who were charged with promoting greater autonomy and had come to age under the shadow of Van Vollenhoven and his adat school. ${ }^{14}$ In 1926, Dr. Haga led an investigation into experimental local government bodies established in 1919 and 1920 that excluded adat functionaries and relied on appointed officials with a civil service orientation. He concluded that they were failures primarily because they were not based on adat and thus commanded little respect in the community. ${ }^{15}$ From this investigation emerged a commitment to bridging the gap between the existing dualistic system of government and unifying the divergent sources of power and legitimacy, Dutch and indigenous.

In a follow-up series of investigations in 1927, the final pieces of the puzzle were put into place and the stage was set for unveiling the pasirahstelsel (system of marga government presided over by pasirah) in 1928. Dr. Haga, based on a one-month observation, concluded that the marga were still functioning, the penjimbang (adat leaders) still enjoyed widespread respect and authority, and all willingly submitted to regular administration of daily affairs by the adat leaders. In an interview with some penjimbang, they declared themselves will-

12 See M. B. Hooker, Adat Law in Modern Indonesia, (New York: Oxford University Press, 1978), especially chap. 1; and the introduction by H. W. J. Sonius, in Van Vollenhoven on Adat Law, ed. J. F. Holleman, KITLV Translation Series no. 20 (The Hague: Martinus Nijhoff, 1981), pp. $29-45$.

13 Van Royen, Nota, pp. 56-57.

14 The historical context is limned in the introduction by E. Adamson Hoebel and A. Arthur Schiller in B. Ter Haar, Adat Law in Indonesia, (New York: Institute of Pacific Relations, 1948), pp. 1-43.

15 Van Royen, Nota, p. 61. 
ing and able to administer the new pasirahstelsel, lending credence to the illusion that was being so assiduously cultivated. ${ }^{16}$

At the same time, a separate inquiry was establishing the fact that Lampung's economy was in good shape and that the Lampungers, especially those producing export commodity crops (some 75 percent of the male adult population) were undertaxed. ${ }^{17}$ However, at the time, it was noted that the marga did not exist as fiscal entities, a shortcoming soon to be rectified. ${ }^{18}$ Following Resident Volmering's final approval of the Haga plan to revivify the marga system, replete with district proatin, the government launched the pasirahstelsel in October 1928. Theoretically, all government power was vested in this new organization, which had the right to levy taxes and regulate the affairs of the people while serving the overarching interests of the state.

Within six months the anti-marga campaign was in full swing, not led by a few extremists or disgruntled pasirah candidates who had been passed over as the local colonial officials would have us believe but, according to Batavia's own assessment, a widespread popular movement that caused sufficient concern to force some grudging reforms, the dismissal of the Resident and reassignment for Van Royen, the adat scholar whose erudition somehow did not translate well on the ground. ${ }^{19}$

\section{Nineteenth-Century Administrative Reforms and Eclipse of the Marga}

As a means of understanding the rapid rise of the anti-marga movement it is critical to trace the manipulation and derogation of adat precepts and institutions under colonial rule up through the reinstallation of adat-based government in 1928. In this discussion, I hope to shed light on the particular exigencies of colonial administration that colored the way the Dutch viewed adat and, in turn, influenced the dialectic between "official" and indigenous adat, thereby perpetuating a dualistic form of administration. Rather than identifying critical junctures or seeking the "kernel of tradition," I elucidate the processes whereby the Dutch created a hybrid form of adat. Their adat was shorn of its social context and religiomythical meaning, resulting in sharply attenuated legitimacy in the community, with grave consequences for the government's attempt to turn it to the state's own ends. Instead of bridging the troubling gap between the state's representatives and the people by unifying the dualistic form of government the Dutch had found so wanting, official adat embodied in the pasirahstelsel came to be regarded with the same ill-concealed contempt that had un-

${ }^{16}$ Ibid., pp. $61-62$.

17 Fievez de Malines van Ginkel, Verslag van de Economischen Toestand en den Belastingdruk met Betrekking tot de Inlandsche Bevolking van de Gewesten Oostkust van Sumatra en Lampongsches Distrikten (Batavia: Landsdrukkerij, 1929), 2: 259, 262-63. This report was based on an inquiry conducted during 1927. In the same year, a separate investigation of taxes in the Outer Islands reported that Lampung had a relatively high tax burden compared to other regions. See Verslag van den Belastingdruk op de Inlandsche Bevolking in de Buitengewesten (Batavia: Landsdrukkerij, 1929). Nonetheless, those favoring the marga system wanted to know that the new bureaucracy attendant to the establishment of the pasirahstelsel could be self-supporting through additional tax levies.

${ }^{18}$ During the 1929 investigation into the anti-marga disturbances, J. W. Van Royen was upbraided by Director of the Interior Administration Muhlenfeld for overzealously striving to strengthen the financial situation of the marga, in effect encouraging the pasirah to engage in excessive and unlawful levies on the people. Mailrapport Geheim 916, 1929.

${ }^{19}$ During de Haze Winkelman's investigation into the anti-marga campaign in August 1929, Van Royen traveled with him, expressing surprise that the marga system he conceived and implemented was encountering such resistance and paving the way for considerable abuses. He disingenuously pretended he had been unaware of what was going on in the province although his responses to attacks on his interpretation of adat carried in 
dermined the previous forms of direct rule, indirect rule, and self-government while the people maintained a parallel system based on their version of their adat. ${ }^{20}$

Van Royen's analysis is a good starting point for a discussion of colonial manipulation of adat because of his thorough research on such intervention and influence and, more importantly, because it is apparent that he was unable to apply the lessons he learned. ${ }^{21} \mathrm{He}$ describes a vacillating approach to adat by colonial authorities dating back to the $1820 \mathrm{~s}$ when Assistant Resident Dubois was the only Dutchman representing the government in a territory the size of central Java. Until 1856, limited resources and more pressing concerns elsewhere in the archipelago severely limited Dutch ability to influence events in Lampung. However, the writings of Dubois on local custom, written in the 1820 s but not published until the 1850s, came to exercise considerable influence on Dutch policy toward adat. ${ }^{22}$

Official policy was set in 1846 when local officials were enjoined from interfering in local affairs any more than absolutely necessary, and the Dutch followed a hands-off approach toward local institutions, laws, leaders, and customs. ${ }^{23}$ This is not to say that the Dutch had confidence in these leaders or institutions, quite the contrary, but they reasoned that other matters on the agenda were more important and that it was best to lay low until such time that they would be able to devote the requisite resources toward bringing Lampung the fruits of colonial administration. Before the "pacification" campaign of 1856, local officials often lamented the absence of "capable" indigenous leaders (ones adept at serving the state's interests) and the people's low regard for any form of government or supralocal authority, echoing Dubois's analysis in the 1820s. ${ }^{24}$

Although this policy was pragmatic while the Dutch had scant power to influence events, it did not sit well after the pacification of 1856 when the Residents were trying to consolidate government power and found their hands tied by the earlier regulation. In their view, the local adat leaders were hopelessly incompetent and hindrances to progress.

Following the drift of Dubois's remarks and driven by their own experience, the Dutch administrators tried to impose a Javanized system, replete with demang assigned to the five (later seven) districts into which Lampung was divided. ${ }^{25}$ Most of the Residents had served in Java where the state had been successful in coopting the local aristocracy of regents and demang into reasonably effective minions of the Dutch. ${ }^{26}$ The Dutch desired such a system

Perasaan indicate that he read the newspaper that gave prominent coverage to the anti-marga campaign. Mailrapport Geheim 926, 1929.

${ }^{20}$ The hybrid nature of the new administrative structure is well reflected in the linguistic mix of Indonesian (pasirah) and Dutch (stelsel).

21 Van Royen, Verdwijning and Nota.

22 J. A. Dubois, "De Lampongsche Distrikten op het eiland Sumatra," Tijdschrift voor Nederlandsch-Indië (hereafter cited as TNI) 14 (1852): 245-73, 309-333; idem, "De Lampong's," TNI, pt. 1, 18 (1856): 547-74 and concluded in idem, "De Lampong's," TNI, pt. 2 , 19 (1857): 1-49, 89-115.

23 Besluit, November 23, 1846.

24 II 09, 1854 Annual Report on Lampung.

25 Broersma, De Lampongsche Districten, p. 45, describes this as the colonial dilemma-whether to rely on locals or recruit outsiders from elsewhere in Indonesia. In his view, the decision to rely on outsiders with limited legitimacy among the people was injurious to Dutch interests, a legacy that persistently plagued the government's efforts to establish effective government in the region. The introduction of demang suggests that western Java, with a long history of influence in Lampung, served as a model.

26 Javanese society was characterized by a developed social hierarchy predicated on the kazula-gusti (servantlord) relationship. The strict obedience to authority embodied therein (at least in the eyes of colonial officials), fueled Dutch perceptions that such a system made the colonial task somewhat easier. Although there is a rich 
in Lampung because they soon found that working through nearly five hundred village heads was hopelessly unwieldy and far too demanding for only seven controleurs. By investing demang with the state's authority, it was hoped that Lampungers would submissively adapt as had been the case in Java where the people had generally followed the bidding of their traditional leaders. The demang thus were charged with the conduct of governmental affairs with the individual villages, although the controleurs intervened as required. Furthermore, the demang provided a buffer between the people and the colonial rulers, at that time an approach imagined to be useful in deflecting anticolonial sentiments. Finding that willingly subordinate, "suitable" local talent was lacking, the Dutch recruited demang from other regions, primarily from Palembang and western Java. These leaders owed their positions entirely to the Dutch and thus could be depended on to act accordingly, unhindered by conflicting loyalties.

Under pressure from the officials on the spot, Batavia approved an administrative reorganization in 1857 that transferred power from the Dutch military officials to civil servants while eliminating the marga heads as officially recognized elements of government administration. In this initiative lay the origins of dual administration in Lampung, the officially sanctioned levels of civil administration initially operating on the periphery of the still functioning indigenous mode of monitoring local affairs embodied in adat. ${ }^{27}$ In imposing a colonial administrative order, the government recognized the villages as the highest level of indigenous political organization, and controleurs theoretically dealt directly with the nearly five hundred individual village chiefs. ${ }^{28}$ In this task they were ostensibly assisted by the demang assigned to each district as the intermediaries between the Dutch and the Lampungers. Although the Dutch had hoped that the colonial imprimatur would confer legitimacy and authority on the demang and foster the establishment of effective district level government, it appears that their extraordinary venality only alienated the Lampungers while their total dependence on the Dutch made it clear whose interests they served. ${ }^{29}$

The dismantling of the marga system was furthered by rescinding recognition of marga territorial authority. Under the new system, the government only recognized the land

history of rebellion in Java, colonial officials assigned to Lampung often expressed concerns about the relatively more unruly nature of Lampung society and praised the virtues of the stable social hierarchy of Java. The attempt to transplant a Javanized system to Lampung reflected this appeal, but ultimately this effort failed because such a rigid hierarchy and unquestioned obedience to authority were entirely alien to Lampung society. For a discussion of how the Dutch sought to mobilize the traditional aristocracy in Java and to transform them from a ruling elite into an administrative class, see Heather Sutherland, The Making of a Bureaucratic Elite: The Colonial Transformation of the Javanese Priyayi (Singapore: Heinemann, 1979), pp. 1-18, 30-44.

27 Besluit June 21, 1857, no. 30.

28 Van Royen, Verdwijning, pp. 181-84, notes that the Resident responsible for drafting the administrative reorganization and withdrawing recognition from the marga and their leaders wrote his recommendation a scant three months after arriving in Lampung. A much different policy was pursued in the Toba Batak area where the Dutch from the outset worked to create and strengthen supravillage institutions articulated in the vernacular of indigenous tradition. See J. C. Vergouwen, The Social Organization and Customary Law of the Toba-Batak of Northern Sumatra (The Hague: Nijhoff, 1964), pp. 127-30. For a discussion of the weakness of district level structures of indigenous systems before colonial intervention that is instructive in assessing the extent to which Lampung's marga can be considered effectively functioning district level institutions, see Lance Castles, "Statelessness and Stateforming Tendencies among the Batak before Colonial Rule" and Christine Dobbin, "The Exercise of Authority in Minangkabau in the Late 18th Century," in Pre-Colonial State Systems in Southeast Asia, ed. Anthony Reid and Lance Castles (Kuala Lumpur: Malaysian Branch of the Royal Asiatic Society, 1979), passim.

${ }^{29}$ There are some parallels with earlier efforts in West Sumatra to create a more centralized district level administration on top of the local village structure. Cf. Elizabeth Graves, The Minangkabau Response to Dutch Colonial 
claims of individual villages up to $6 \mathrm{~km}$ from the village and $3 \mathrm{~km}$ from the umbul, temporary settlements established by villages that were opening up virgin territory for swidden cultivation. ${ }^{30}$ The land in-between the village claims, formerly the common marga territory, now came under state control. ${ }^{31}$ This was a critical decision with far-reaching implications, for the Dutch had abolished, at least on paper, the authority over land use formerly exercised by marga leaders and thus the basis of their power and wealth. ${ }^{32}$ Not surprisingly, this ele vation of the village head's status, who had no standing in adat, vis-àvis the traditional adat leaders unleashed intrigues detrimental to effective administration.

The situation was further complicated by the influx of Buginese and migrants from Palembang and Java who settled in the interstices that had formerly been marga land but had reverted to public domain under terms of the 1857 reorganization. As noted, the virgin land lying between village claims formerly came under the authority of the marga, which allocated usufructory rights, territory that the swidden Lampungers depended on for crop rotation. ${ }^{33}$ The new migrants did not pay compensation on what had been marga land, the shared patrimony of the villages that comprised the marga, demonstrating the impotence of the traditional leadership. Now they were not permitted to enforce local adat obligations nor could they protect the people's traditional claims to a land frontier, eclipsed in the shadow of Dutch rule. ${ }^{34}$ Apparently, the influx of migrants, particularly in the northern districts, undermined Lampungers' livelihood because their rights over forest products, formerly recognized within the marga system, lay in abeyance. ${ }^{35}$

Even though the government reversed itself and restored marga land rights in 1869, an 1872 inquiry into land tenure in Lampung reported that irreparable damage had been done to the marga system during the twelve-year hiatus in recognizing marga land rights, and as a consequence, social harmony continued to be undermined by land disputes arising from what this report described as a misguided initiative. ${ }^{36}$

However, by virtue of the 1874 Agrarian Law for Sumatra, which regulated land tenure in Lampung, the government reversed itself yet again and declared the territory lying outside village jurisdiction to be "waste ground," unused land, the rights over which reverted to the state. ${ }^{37}$ Although this decision regarding land tenure in Lampung ran expressly counter to the findings and recommendations of the 1872 tenure inquiry, it was consistent

Rule in the 19th Century, Modern Indonesian Project monograph series no. 60 (Ithaca, N.Y.: Cornell University, 1981), pp. 29-49.

${ }^{30}$ Broersma, De Lampongsche Districten, p. 56.

31 Here are some rough parallels with British interventions to free land in Burma and New Zealand; cf. Michael Adas, The Burma Delta: Economic Development and Social Change on an Asian Rice Frontier 1852-1941 (Madison: University of Wisconsin Press, 1974); lan Hugh Kowharu, Maori Land Tenure: Studies of a Changing Institution (London: Oxford University Press, 1977).

32 Sonius, in Holleman, Van Vollenhoven, p. xxxiii, discusses the consequences of undermining the self-sufficiency of the adat communities particularly with regard to Van Vollenhoven's efforts.

33 See Resumé van het Onderzoek naar de Regten welke in de Gouvernements Landen op Sumatra op de Onbebouwde Gronden Worden Uitgeoefend, Section C- Lampongsche Distrikten, (Batavia: Landsdrukkerij, 1896 [1872]), pp. 110134.

34 Elsewhere in Sumatra the Dutch employed somewhat different means to achieve the same goal of breaking down indigenous control over the land frontier; cf. Karl Pelzer, Planter and Peasant: Colonial Policy and the Agrarian Struggle in East Sumatra 1863-1947 (The Hague: Nijhoff, 1978), VKI 84, pp. 66-85.

35 Resumé, p. 123.

36 Ibid.

37 Staatsblad 1874, no. $94 f$. 
with the colonial objective of enhancing the feasibility and security of developing a plantation sector, permitting the state to grant long leases on choice lands that had formed the economic basis of the marga system. ${ }^{38}$

The vacillating and debilitating policy towards marga land rights was paralleled by changing attitudes and policies towards the roles of marga heads, the village chiefs and imported demang in nineteenth-century colonial administration, fostering confusion and strongly influencing the role of adat. What was euphemistically referred to as self-government, the rule of like over like underneath the umbrella of Dutch authority, was a grave disappointment to the government and a source of bitter bureaucratic recriminations. It can be said with some certainty that with each rotation of Residents that which was emphasized, vilified, or glorified in local affairs changed dramatically.

Within eighteen months of the 1857 reorganization, the Resident who supported it was arguing that the circumstances were not propitious for self-government as outlined, particularly in light of the necessity to consolidate government authority and institute proper administrative mechanisms; it was not possible to achieve this goal through the indirect system of rule whereby the controleurs worked through the dispersed village heads. ${ }^{39}$ In Resident Wijnen's view, the authorities had to overcome the "state of anarchy" (i.e., resistance to colonial rule) that prevailed before annexation and the detrimental impact this absence of institutional organization had on social cohesion and administrative efficiency. In his opinion, the village heads were a contemptible lot, and the people needed the Dutch authorities to step in to protect them from excessive exploitation. The frequent arrests of village heads attest to the problems plaguing the reorganization efforts. Nonetheless, according to Resident Wijnen in 1858, despite "pernicious and obnoxious" adat influences, indigenous officials sadly lacking in the right virtues, and so forth, the government was making progress and could make more if local colonial officials' hands were not tied by having to perpetuate what he described as the charade of self-government.

In the following year, the Resident directed his attacks against the demang recruited from outside Lampung, the layer of administrative authority that had been created at the district level, dismissing all but one for various offenses related to abuses of authority ${ }^{40} \mathrm{It}$ was generally recognized that the demang as well as the village heads exacted illegal levies from the people, and some Residents advocated that they be salaried to minimize the abuses.

One of the controleurs in the northern district of Menggala took the initiative to reform the system of self-government, by taking a page from the Cultivation System. In his district each household was required to plant ten coffee and pepper trees each year for five years to provide income for the village heads in the hope that it would lessen their need to extort money from their villagers. This initiative was only undertaken in one of the five districts in Lampung and was abandoned soon thereafter. Unfortunately, the archives are not usually so detailed about regional variations or the permutations of policy implementation as it filtered from the center of the bureaucracy out into the far-flung provinces where individual

\footnotetext{
${ }^{38}$ Resumé, p. 131. The report is mostly written by a controleur who concludes that the term "waste ground" is irrelevant in the context of Lampung land tenure rights for the land claims of the marga ran concurrently, and given the nature of swidden cultivation, today's unused land was next year's field. The Resident interjected his analysis, which peppers the text, essentially arguing that the people actually recognized the government's claim to all land, buttressing the subsequent decision embodied in the 1874 Agrarian Law for Sumatra.

${ }^{39}$ II 06, 1858 Annual Report on Lampung.

40 III 07, 1859 Political Report on Lampung.
} 
controleurs exercised considerable independence and discretion, belying the scope of official policy and historical generalizations. Nevertheless, it is safe to say that endemic corruption and exploitation of the people by the village heads and demang persistently undermined Dutch efforts to institute what they viewed as effective governance and to cultivate leaders with legitimacy in the community. Frustrated with attempts to promote self-government along these lines, a rising clamor for direct rule suggested the axiom that if you want the job done right you must do it yourself. "Lampungers have no political or domestic laws and no unified legal system and the greatest favor that the European officials can confer is to govern them." 41

Perhaps signifying the beneficial influence of able administration or unfamiliarity with a new job, scarcely two years later all the kinks in the system of self-government ostensibly had been worked out and the new Resident proudly acclaimed the virtues of the system and the benefits it had already apparently conferred. ${ }^{42}$ By this time, the attitude of the local leaders toward the colonial administration had noticeably improved and tellingly, "It would be difficult otherwise since the government has essentially made them into properly functioning heads." 43 However, the question of effective government was not limited to cordial relations between the Dutch and their minions, and the illusion of self-government could not be sustained in dispatches for consumption in Batavia.

In 1867, the Resident made a scathing attack on the "myth" of self-government and noted the de facto direct rule exercised by local controleurs. ${ }^{44}$ The village heads and demang had little influence among the people, who viewed them largely as unsavory deputies of the controleurs, and only received grudging acceptance, based on the realities of the colonial situation and pragmatic realization of where the preponderance of power lay. Various new policy reforms were circulated but not enacted, and the myth of self-government was allowed to continue, no doubt aided by institutional inertia and regular rotation of the Residents. Generally serving three-year tours or so, and with scant resources at their disposal, after initially venting frustration, the Residents probably found that exposing colonial myths was not necessarily in their best interests and bided their time waiting for the next assignments. Then they could write up their final assessments of the situation in the province in the Memorie van Overgave, for use by their successors, often excluding the problems, abuses, and mistakes evident in the monthly and yearly reports, handing over power to the next Resident ostensibly with all affairs in a satisfactory state. Upon discovering the gap between the rather rosy picture conveyed in the Memorie van Overgave and reality, the new Resident would also briefly turn reformer, turn in a few reports about the futility of various policies, come to terms with the situation, and soon be rotated. 45

The dual administration began to congeal with the "official" self-government on one side and the indigenous adat leaders holding sway within their limited domain. As Broersma and Van Royen argue, the two operated independently of one another and be-

41 III 08, 1860 Political Report on Lampung, p. 4.

42 III 09, 1862 Political Report on Lampung.

43 Ibid.

44 III 15, 1867 Political Report on Lampung.

45 III 19, 1872 Political Report. The new Resident essentially exposes the same myth that had been exposed in 1867 , noting that all decisions and authority rested with the Resident and his controleurs, whereas the demang, still mostly non-Lampungers, and village heads lacked authority. He again urged reforms as his predecessor had done, arguing that the abuses of these officials reflected badly on the government. For comments on the detrimental impact of the high turnover rate and the low caliber of officials assigned to Lampung see Broersma, De Lampongsche Districten, p. 33. 
cause the government did not systematically or directly interfere in the affairs of the adat leaders, the adat system was allowed to flourish as it always had. The archival evidence reviewed above, much of it also surveyed by Van Royen, suggests that this was not the case, rather, the sharp delineation of adat authority and competence by colonial authorities fundamentally altered adat, both the way it functioned and the way it was viewed within the community. The adat leader's role as ultimate arbiter of all matters concerning society was sundered, and the adat system was only permitted to operate in areas that were not crucial to colonial interests. Control over land, taxes, justice, and mediation of affairs with the outside world, formerly within the broad sphere of adat and areas where adat leaders had exercised considerable sway, was suddenly taken over by the Dutch and disrupted. Under the influence of colonialism and the rise of Islam, the sources of power, legitimacy, and authority in the community multiplied, becoming confused and entangled, diluting the sway of adat among the people and substantially transforming it. ${ }^{46}$ Adat was accorded a niche within which it could develop and adapt and continued to play a complementary role in the colonial system by regulating household and local affairs. The system of legal pluralism established in a hodge podge manner "posited a number of sovereign law systems, but at the same time political sovereignty rested in the institutions of only one of these systems." 47

Given the limited presence of the Dutch in nineteenth-century Lampung, it is important not to overestimate the scope of Dutch authority and the extent to which it impinged on adat. But just the same, the growing presence of Dutch authority and the absence of any unified opposition capable of defending the integrity of local institutions ensured that the state's desires were more likely to be fulfilled in critical areas than were those of the traditional leaders.

During this time, the indigenous adat system was not entirely tamed but was kept on a long leash by the colonial authorities. As with a child walking a large dog, sometimes it was difficult to discern who was being walked by whom. Clearly, traditional adat leaders continued to exercise considerable influence while the lack of standing in adat undermined the positions of the demang and village heads who remained beholden to the Dutch for their authority. Moreover, the evident concern of Dutch administrators for adat institutions, leaders, and relations expressed in their reports indicate that tradition also circumscribed their actions. Official policies and institutions were conditioned by adat. Yet, the colonial authorities had the power to assertively intervene, manipulate, and transform the adat system and dissected it into distinct spheres of competence while retaining the ultimate power of veto. For the adat community, passive resistance, noncooperation, and Brechtian compliance-the "weapons of the weak" -often proved inadequate to sustain the integrity of the system. There was a dialectic between the various systems and sources of law and authority, but the

\footnotetext{
46 Unfortunately, there are only sketchy archival references to the influence of Islam in Lampung, generally suggesting that from the latter half of the nineteenth century it was an increasingly influential social force. The lively trade in pepper funded the large number of haji from Lampung. It is probable that the conflict between, and accommodation of, adat and Islam as sources of authority among the people noted elsewhere in the Malay world had parallels in Lampung. See P. E. de Josselin de Jong, Minangkabau and Negeri Sembilan: Socio-Political Structure in Indonesia (Leiden: Idjo, 1951); Taufik Abdullah, "Adat and Islam: An Examination of Conflict in Minangkabau," Indonesia 2 (1966); Michael Peletz, Social History and Evolution in the Interrelationship of Adat and Islam in Rembau, Negeri Sembilan, Research Notes and Miscellaneous Papers no. 27 (Singapore: Institute of Southeast Asian Studies, 1981).

${ }^{47}$ Hooker, Adat Law, p. 62. For an elegant analysis of this theme with respect to South Sumatra see M. A. Jaspan, "In Quest of New Law: The Perplexity of Legal Syncretism in Indonesia," Comparative Studies of Society and History 7 (3): 252-66.
} 
reverberations were certainly more strongly experienced and the changes were more dramatic among the colonized.

\section{Reforming Adat and Constructing "Tradition"}

From the outset of Dutch rule in the 1820s, local officials expressed reservations about various aspects of what was regarded as customary law, adat with legal consequences, and blamed many of Lampung's ills, such as economic backwardness and underpopulation, on what they viewed as noxious aspects of adat. In Dubois, the low level of economic development is attributed to population scarcity, itself the result of a system of inordinately high bride price payments (jujur) that kept many men unmarried. ${ }^{48}$ Reforming or abolishing this system became a priority of subsequent Residents eager to confer the fruits of civilization. By 1860 , the government had officially banned bride payments and the morally troublesome practice whereby widows were obliged to marry their husband's oldest living brother. The Resident at the time confidently noted that very few bride payments had been reported and the price had declined. ${ }^{49}$ However, subsequent reports indicated that jujur payments persisted on the sly, tolerated to some degree by the Dutch who, after all, had limited ability to monitor local affairs. ${ }^{50}$ Nonetheless, even though the general system persisted, the withdrawal of official sanction in a world increasingly influenced by official policies over time altered the jujur system and branded it as an archaic remnant that was only permitted to persist surreptitiously. By removing these practices from the permissible public arena, the official forum for the conduct of affairs, and transferring it to the quasi-public realm, one senses that the meaning of the custom, if not the substance, was significantly altered under Western pressures. ${ }^{51}$ Thus, even though Van Royen can identify certain elements of adat in the 1920s that broadly resemble practices, at least in their outward form, as described by nineteenth-century colonial observers, it may be quite erroneous to view these as evidence that adat had persisted in its original form. They would, perhaps, be better described as illustrations of hybrid adat cultivated in the hot house of colonial rule.

Such is particularly relevant to the adat status system, pepadon, described in detail by Van Royen. 52 Drawing on various colonial accounts of pepadon and the manner in which members of the community could improve their status by fulfilling material and ritual obligations specified in adat, Van Royen rejected the prevailing view that the substantial payments made to local adat elites by those seeking to elevate their status within the adat hierarchy were merely trades in titles by exploiters of the people. It is precisely this trade in titles that is specified as one of the chief abuses of adat criticized in the local vernacular press. Van Royen seeks to demonstrate in detail how such practices were consistent with traditional practices not driven by avarice or merely temporal concerns. The pepadon ceremonies held to improve one's status were sacral adat rites with great symbolic meaning that derived from time-honored concepts of the community's ruling structure and how social relations ought to be conducted.

\footnotetext{
48 Dubois, "Lampongs," p. 114.

49 IV 08, October 1860 Monthly Report for Lampung.

${ }^{50}$ Broersma, De Lampongsche Districten, pp. 64-89.

51 For a discussion of the cultural and class ramifications of intervention in the system of bride payments in Bengkulu that parallels Lampung's experience, see J.J.J. M. Wuisman, Sociale Verandering in Bengkulu: Een Cultuur-Sociologische Analyze (Dordrecht: Foris, 1985), VKI 109; 44-99, 199-219.

52 J. W. Van Royen, "De Staatkundige Zijde van het Pepadonwezen," Koloniale Studien 12 (1928): 419-51.
} 
This reified interpretation of pepadon is at odds with the interpretation of the system of title acquisition so strongly criticized in the pages of Perasaan and Fadjar Sumatera. It is certain that Van Royen was better informed than most Lampungers about how the system worked historically and in detail, having rescued the "kernel of tradition" from the obscurity of archival and secondary sources written by other Dutch scholars, but his erudition missed the point.

Those protesting the imposed marga system of government argued that the trade in titles embodied in the pepadon system was an archaic feudal remnant that kept people under the yoke of tradition and produced leaders with limited abilities and substantial greed. Numerous articles complained about the waste of vast resources on the purchasing of titles, money that accumulated in the hands of the traditional elite and sapped the economy. ${ }^{53}$ Moreover, in contrast to the ethereal view of pepadon in Van Royen, there was a strong sense that material motives prompted the acquisition of titles. Under the 1928 marga system, only titled Lampungers, those who had attained status in the pepadon system, were eligible to become pasirah or to be named to the proatin.

These positions were sought because of the opportunities for acquiring wealth through legal and illegal levies. Many people suddenly were willing to pay substantial sums to acquire a title not because of a great revival of traditionalism that swept Lampung in the late 1920 s but because titles, and the access they provided to positions in the marga administration, were extremely lucrative. These opportunities for enrichment had not been so staggering before the rigidification of the elite system, and it was the erosion of reciprocity between ruler and ruled fostered under colonialism and its need for "effective " rulers that took the abuses to new levels. ${ }^{54}$ Previously the people could flee a ruler who proved too exacting, too willing to exercise all his prerogatives, but this was no longer an option with the tighter Dutch regulations on residence and the ban on splitting off to form new settlements. The rules had been tilted in the elites' favor and bore heavily on the people. ${ }^{55}$ The system had probably not always functioned in this manner, but changes in the ground rules initiated by the Dutch belie Van Royen's depiction of what constituted "true" adat.

It is generally accepted among adat scholars that historically two main systems of adat functioned in Lampung: that prevailing in the southern coastal regions reflecting strong external influences and that characteristic of the central and northern interior that had developed with relatively minor external influence. ${ }^{56}$ Overall, the marga system in southern Lampung was more authoritarian and hierarchical than that prevailing in inland areas, with a much higher concentration of power in the marga heads who exercised autocratic power at the behest of and with the backing of the sultan of Bantam since the fifteenth century. ${ }^{57}$

\footnotetext{
53 For example, Fadjar Soematera, May 28, 1930, no. 18. This Malay language newspaper was published twice a week in Teluk Betung between March and December 1930.

54 Rigidification of elite ruling structures and the erosion of reciprocal patron-client relations under colonial rule lay at the heart of the "moral economy" thesis. For example, see James Scott, The Moral Economy of the Peasant: Rebellion and Subsistence in Southeast Asia (New Haven: Yale University Press, 1976).

55 Broersma, De Lampongsche Districten, p. 47; Van Royen, Nota, p. 45.

56 There were a multitude of local and regional variations in and among the various ethnic groups resident in Lampung, but in terms of political organizational differences pertinent to this discussion, this crude categorization is useful. A full cataloging of the local variations of adat practices is included in Van Royen, Nota.

57 In the Minangkabau heartland, a similar distinction is made between the Koto Piliang and Bodi Caniago adat systems whereas on the coastal periphery a class of nobility had formed based on the control of trade access analogous to the situation on the Lampung littoral. See Graves, Minangkabau Response, and Dobbin, "Exercises of Authority." Castles, "Statelessness," notes a similar phenomenon of a more hierarchical, authoritarian system
} 
More centralized political organization had developed in these areas probably owing to the greater threats encountered (piracy was rampant in the coastal inlets) and because authority was conferred and occasionally reinforced by a supralocal power. Van Royen and others argued that this system was a degeneration of the true Lampung adat. ${ }^{58}$ Ironically, in his view, external forces had undermined the essentially egalitarian and republican nature of Lampung social organization, a view that was shared by the Comite Tani Lampung with respect to Dutch intervention in renovating the marga system based on the coastal adat system.

According to Van Royen, to discover Lampung's original adat one merely had to travel to Lampung's interior up the waterways, a veritable riverine time machine, where adat as it always had been practiced still persisted even up through the $1920 \mathrm{~s} .{ }^{59}$ In Lampung's interior, each community existed quite independently without strong leaders and there was no evidence of the quasi-autocratic social organization that had previously characterized coastal areas. As Dubois had noted in the 1820 s, each community acted as its own republic and there was no centralized power to speak of, a condition that Van Royen saw persisting into the twentieth century. 60

In choosing a model for the 1928 marga system, the southern, coastal version with its more tightly organized, hierarchical organization more clearly approximated the needs of the government. Thus despite the recognition of vast regional variations, the state imposed a uniform, highly centralized marga system throughout Lampung. Yet, this was in 1928 and the quasi-autocratic system of the south had undergone dramatic changes in the preceding two centuries.

To briefly summarize, the power of Banten receded dramatically from the end of the seventeenth century onward, presumably weakening to some degree the position of the coastal oligarchy the sultan had nurtured to monitor his pepper monopoly. What Dubois encountered in the 1820 s was a system where a few marga heads, primus inter pares, had managed to get the upper hand in the vacuum of power left in the wake of Banten's steady decline, but even then their power was circumscribed, vacillating, and hardly absolute. It was these relatively powerful marga heads who had sowed considerable unrest in Lampung until the pacification campaign of 1856. Subsequently, Dutch policies in Lampung were aimed at removing the political threat posed by powerful marga heads, and they did their best to undermine these traditional leaders until 1928, which encouraged centrifugal tendencies by elevating lower level village leaders in the official administration and imposing alien, district level demang to stem coordinated supralocal resistance to colonial encroachments. Thus not only was the 1928 system at odds with custom in the northern areas but it can equally be argued that it was based on a model no longer even characteristic of the southern regions. The processes of selection, exaggeration, dilution, and conversion executed by the colonial officials with regard to Lampung's traditions knew no regional boundaries.

existing in Tapanuli's southern periphery, suggesting that this was a response to external challenges as is argued for Lampung.

58 Van Royen, Nota, pp. 15-37; Broersma, De Lampongsche Districten, pp. 42-44. Broersma goes as far as to speak of the coastal areas losing adat.

59 Van Royen, Pepadonwezen, p. 421. He argues against the views of earlier observers who saw the autocratic system as Lampung's true adat and the loose knit, democratic system of the interior as a degeneration.

60 Dubois, De Lampong's, p. 91. 
The government efforts to revive the marga system were also plagued by the difficulty in determining who the legitimate pasirah was in a particular locality, especially in inland areas where there was a tendency for genealogical groups, the basis of the marga, to intermingle within officially designated marga territories or to split internally and form distinct groups within a marga. ${ }^{61}$ In this way, the Dutch sanctioned the rise of some elites with only a tenuous claim to the pasirah position and generated controversy and opposition. In other cases, the state simplified matters, at least administratively, by conglomerating separate margas into an umbrella marga under one head. In either case, popular support for the 1928 marga system waned considerably.

\section{Justice}

Nowhere, perhaps, were the Dutch efforts toward manipulating adat as sustained as in the field of adat law and the administration of justice. These attempts hit at the heart of adat, and the consequences were enormous. And yet, the administration of customary law-the officially sanctioned version as well as the indigenous system-also illustrates the limitations of colonial authority.

A major concern for the Dutch was the administration of adat justice that broached Dutch notions of fairness and equity and, therefore, was subject to substantial intervention. "Adat law" was a concoction of Dutchmen, defined by Snouck Hurgronje as adat that carries legal consequences. It is now generally accepted that this taxonomic approach to adat, distinguishing between various elements of adat and emphasizing certain features to the detriment of others, is inconsistent with the manner in which adat was viewed and practiced in the indigenous community ${ }^{62}$ It is argued that adat notions of justice emphasized compromise between parties that would restore harmony within the community, whereas "Rights and duties are not absolute or fixed principles, but are relative according to the proper behavior adat requires from specific individuals." 63

These subjective aspects of what the Dutch termed adat law with the emphasis on social context and restoration of harmony rankled the official mind and culturally rooted sense of justice. Dubois's writings provided substantial ammunition to adat reformers and prompted aggressive intervention. He described a system of penalties in which corporal punishment and imprisonment were wholly absent. In the most extreme cases, a member could be banished from the community, but generally, even for murder, adat prescribed fines and conciliatory feasts proportionate to the rank of the victim and transgressor. ${ }^{64}$ For theft, the thief had to compensate double the value of the items stolen and hold a feast. In cases of murder, depending on the relative rank of the individuals involved, elaborate rituals were enacted to restore harmony: the murderer paid substantial monetary fines, delivered bolts of white cloth, slaughtered water buffaloes, offered fresh human heads, and if the victim had been high ranking, performed irawan, the sacrifice of a slave strapped to a pole who was slashed to death in a dance ritual to atone for his owner's transgression. ${ }^{65}$ Should a slave murder a member of the adat community (slaves, constituting 20 percent of the population, were

\footnotetext{
61 Van Royen, Nota, p. 64; Ter Haar, Adat Law, pp. 60-61.

62 Hooker, "Adat Law," p. 59. Jaspan, "Quest of New Law," asserts that "adat law was not a separate and independent entity, but was in most cases intertwined with the history, mythology and institutional charters."

63 Hooker, "Adat Law," p. 54.

64 Described in Dubois, "Lampongsche Distrikten," pp. 255-56.

65 Irawan was separately verified by Captain Jackson on his travels up the Tulang Bawang river. Malayan Miscellanies 2 (1822): 6-7.
} 
excluded from adat) the slave's entire family was subject to massacre. ${ }^{66}$ However, adat did proscribe murder of slaves, albeit the penalties were lighter than those enforced for killing those with adat. People of lesser means were subject to debt bondage, an apparently prevalent practice. ${ }^{67} \mathrm{It}$ is not surprising that such a system of penalties and judgments, dependent on who did what to whom under which circumstances, was anathema to Western notions of equality before the law, bureaucratic tidiness, reliance on precedent, and generally applicable principles involving sentences of corporal punishment and/or imprisonment.

Rules of testimony and evidence also varied from Western practices; neither was as formal or rigid in practice. What a Western judge might have viewed as irrelevant to the case would have been considered eminently relevant contextual detail in terms of adat sense of justice. In Lampung, the testimony of two reliable witnesses, excluding women and slaves, was sufficient for conviction. ${ }^{68}$ In the absence of witnesses, an accused person faced a variety of tests to determine culpability. Hukum silem required the accused to write separately on two pieces of bamboo, "I'm guilty," "I'm not guilty," and to wrap each individually in cloth. Two children each took one bamboo, dove to the bottom of the river, and released it. The decision hinged on which piece of bamboo surfaced first. ${ }^{69}$ Of the variety of such early versions of the lie detector, none were deemed sufficiently reliable by Dutch administrators, who were confident in their belief that their system of justice was somehow less arbitrary. ${ }^{70}$

The Dutch strategy of promoting justice in Lampung was based on creating courts with the trappings of adat while ensuring that adat did not hinder the proper administration of law. ${ }^{71}$ Actually, the Dutch relied on a pluralistic system, permitting recourse to Dutch law for Europeans and non-Indonesians and making it mandatory in serious criminal cases, whereas civil disputes and lesser criminal cases were normally handled by the official proatin. ${ }^{72}$ Here, I will concentrate on the proatin as examples of the manner in which the Dutch manipulated adat and fostered changes therein that belie the premise that the indigenous adat system was able to persist in essentially unaltered form until 1928.

Dubois, the standard source on Lampung tradition, had referred to proatin as mediating courts composed of adat officials but noted that there were no clear principles of law. ${ }^{73}$ Usually the adat leaders (penjimbang) presiding in the courts were compensated by onefifth of the amount in question, which was deducted from the money both parties were obliged to deposit with the proatin until the case was settled. ${ }^{74}$ These penjimbang acted as

${ }^{66}$ Dubois, "Lampongsche Distrikten," pp. 259, 330.

${ }^{67}$ H.F.W. Cornets de Groot, "Note Over Slavernij en het Pandelingschap in de Residentie Lampongsche Distrikten," Tijdschrift voor Indische Taal-, Land en Volkenkunde (hereafter TBG) 27 (1882): 452-88.

68 Dubois, "Lampongsche Distrikten," p. 261.

${ }^{69}$ Ibid., pp. 262-63.

${ }^{70} \mathrm{II} 03,1838$ Annual Report on Lampung. The reporter argued that justice could not be served by relying on the rules of a lower civilization.

${ }^{71}$ IV 06, June 1856 Monthly Report on Lampung. All of the sentences announced in the adat courts established by the Dutch, proatin, were announced in the name of the Raad van Volkshoofden even if they were passed by the controleur.

72 Gradually, the Dutch increasingly encroached on this division of labor, and after the 1879 reorganization, the government was handling cases directly and the official proatin were abolished.

73 Dubois, "De Lampongs," p. 113.

${ }^{74}$ Dubois, "Lampongsche Distrikten," p. 252. 
arbitrators in adat disputes but did not, at least in Dubois's account, exercise powers of governance. ${ }^{75}$

Following the pacification of Lampung in 1856, the Dutch moved quickly to promote peace and order (ruste en orde) by establishing district level proatin composed of members chosen by the local Dutch officials, generally village heads who lacked standing in adat because most were not penjimbang. Thus, those charged with enforcing adat, the village heads, were given the power to adjudicate that in which they were not well versed but supervised by the Dutch controleur. The Dutch hoped that by thus reforming the system of justice and removing the meddlesome traditional adat leaders the problem of unpunished crime could be resolved. ${ }^{76}$ In the case of adat this appears to be "the blind leading the blind" as the proatin rendered decisions based on inadequate knowledge of adat and gave inconsistent interpretations. Furthermore, in cases where the decision of the proatin offended Dutch notions of justice and equity, the controleurs or Residents would intervene and render their own decisions. Particularly in terms of sentencing, controleurs would intervene to ensure that offenders did not get off too lightly. They would also intervene to ensure speedy decisions and enforced equality before the courts as the basis for instilling greater respect for law. ${ }^{77}$ Such was the manner in which official adat developed under the aegis of colonial paternalism.

Following the establishment of the government proatin in 1857, it appears that the village heads appointed to the proatin gradually got the hang of "official" adat under the assertive tutelage of Dutch controleurs. Before these proatin were established, adat cases had been known to drag on for several years, but under the new system prompt resolution of cases became the norm. One controleur decided ninety-seven cases in his first week on the job, a burdensome obligation that left him requesting a proatin for his district to help speed the prosecution of justice. ${ }^{78}$

By 1859, the Resident expressed satisfaction with the new proatin not so much because the village heads had rapidly become experts in adat but because they knew the drill and could be effectively controlled by the state. The Dutch turned the passiveness and ignorance of the village heads to their advantage by having the controleur assume a critical role in the proceedings. The deferential village heads usually knew little of the cases they were hearing and invariably requested controleurs' advice on how they would like them to adjudicate the cases. Although the controleurs may have known little about adat or the case themselves, they did know where the state's interests lay, and the controleurs' dominant role in the adat courts led subsequent Residents to reassure Batavia that all was in hand and that the proatin's decisions were generally fair and consistent with Dutch notions of justice. Translating Western legal customs via adat was often tedious and cumbersome, but in general, the state was satisfied that its interests were served therein. ${ }^{79}$

\footnotetext{
75 Dubois, “De Lampongs," p. 91; also Broersma, De Lampongs, p. 41.

76 II 09, 1854 Annual Report on Lampung.

77 II 14, 1859 Annual Report on Lampung.

78 IV 06, June 1858 Monthly Report on Lampung. However, elsewhere it was reasoned that the slow wheels of justice in adat justice were preferred out of fear that the opposing party might get an advantage. Thus no decision was preferred, and in the meantime, there was always a chance for reconciliation. See III 06, 1858 Annual Report for Lampung. The new rapid fire-system of adjudication may have contributed order to what appeared chaotic from a bureaucratic perspective, but it is not clear that justice was promoted thereby.

79 III 12, 1864 Political Report for Lampung; III 16, 1868 Political Report for Lampung.
} 
The people of Lampung, however, must have had serious doubts about the legitimacy of the government's proatin that comprised judges with no standing in or knowledge of adat who were clearly exercising power at the controleurs' behest. ${ }^{80}$ Many of the decisions and punishments handed down by the proatin, ostensibly the institutional guardian of adat, must have generated considerable resentment and confusion. Lack of punctuality suddenly became a punishable offense, as eight village heads were sentenced to four days imprisonment for appearing late at the proatin proceedings, apparently an unpardonable disrespect that, perhaps, indicated the low esteem accorded the official proatin in the community. ${ }^{81}$ Other village heads were sentenced for not carrying out government orders, such as mobilizing labor for road construction, and another was called to task for not reporting the presence of a political undesirable, an escaped dwangarbeider (forced labor convict), in his village. ${ }^{82}$

One case in 1877 clearly illustrates how large the gap between indigenous adat and "official" adat had grown nearly twenty years after the genesis of the latter. The controleur noted that twenty armed men from one village had entered a neighboring village, surrounded one house to retrieve a young women who had been kidnapped, and were on the verge of committing violence. In his report, the controleur praises the timely intervention of the local constabulary and maintains that otherwise a grave incident would certainly have occurred. ${ }^{83}$ As a consequence of this incident, both village heads were sentenced to one year at hard labor.

Had the controleur more diligently studied Lampung customs, he might have read Dubois's description published in 1852 of the elaborate ritual that attends marriages by elopement, a common alternative in cases where marriage was desired by both parties, but the man could not afford the bride payment. ${ }^{84}$ The mock warfare scene witnessed by the controleur was a prelude to negotiations between the two families about appropriate compensation. Certainly in the eyes of the community, the harsh sentences were a great injustice wholly at odds with indigenous adat and community norms.

Such cases sapped the proatin of any vestiges of legitimacy, exposing them as tools of colonial administration and repression. Reports are numerous of adjudication within the villages by recognized, competent adat leaders in preference to submitting cases to the government's proatin. There was no question that the official proatin members served the state's interests over those of the community because members could be removed from the proatin at the Resident's discretion. Because participation in the proatin was lucrative, members sharing in the levy on each case, there were strong financial inducements to hew to the government line. Those who acted in the community's interests could be weeded out and the official proatin, therefore, primarily provided the trappings of adat for decisions that ultimately emanated from the colonial overlords. The people were loathe to submit

\footnotetext{
80 The venue and the process are part and parcel of adat, and it was inevitably influenced by colonial intervention in the judicial system. As is argued elsewhere, "In adat the substantive content of a rule cannot be sharply divorced from the decision making process in which the rule is applied." See Keebet van Benda Beckmann, "Traditional Values in a Non-Traditional Context: Adat and State Courts in West Sumatra," Indonesia Circle 27 (March 1982): 46.

81 III 17, 1870 Political Report for Lampung.

82 III 15, 1867 Political Report for Lampung.

83 IV 24, February 1877 Monthly Report for Lampung; II 38, 1878 Annual Report for Lampung.

84 Dubois, "Lampongsche Distrikten," p. 265.
} 
themselves to what must have been viewed as the arbitrary and incomprehensible administration of justice by the government's proatin, rightly fearing that it was a dangerous gamble, for their cases were decided out of the social context that formed the basis for adat rules. As Jaspan relates:

The adat tribunals, now stripped of their authority as recognized juridical bodies, continue to play a dominant part in the actual legal intercourse of everyday life. Even though they can only mediate, advise or dissuade they are still able to meet the people's needs. Village people know that if they take their disputes outside the village (to the government courts) they are likely to run into unforeseen and usually unpleasant complications. ${ }^{85}$

Although Jaspan was describing post-World War II Jambi, his analysis is remarkably telling for nineteenth-century Lampung.

The archives describe one case in which a man sentenced by the proatin asked the presiding controleur if the sentence had been imposed by the proatin or the controleur. Upon learning that his ten-year sentence was the proatin's decision, the man pleaded with the controleur to sentence him to twenty years, expressing shame that the proatin had sentenced him and unwillingness to submit to its authority. ${ }^{86}$ For the colonial officials, this was construed as evidence of the peoples' desire for colonial rule and justification of their presence, but from a different vantage, it underscores the illusory legitimacy of the proatin, adat trappings aside, and recognition by the people that the ultimate arbiters of justice were those with power, the Dutch.

The elevation of the village heads vis-à-vis traditional adat leaders, penjimbang, did not sit well with the community, and paralleling the "official" adat tribunals, the people continued to seek justice in indigenous adat administered by traditional adat leaders. This was dualism at work, with the indigenous version operating in the shadows. Although it is clear that the people continued to seek recourse in their indigenous institutions and leaders, I argue that this does not mean that the precolonial social formation emerged unscathed. The intrusion and encroachment on the sway of the indigenous side of dualism ensured that its position in the community eroded, and by the twentieth century, the gradual derogation of authority had taken a considerable toll.

\section{The "Watershed"}

In 1879, following yet another administrative reorganization that reconfirmed the role of demang and village heads and drew heavily on Western notions of justice and administration, the government held a grand feast to celebrate this ineluctable step toward progress, inviting all of the local dignitaries. However, the penjimbang were notable by their absence and dutifully listed as sick and unable to attend. ${ }^{87}$ This silent protest against their exclusion from power and the reworking of indigenous institutions and mechanisms of justice in the image of their master bears eloquent testimony to their dissatisfaction with the role allotted them under the dualistic system.

Although Van Royen looks at this administrative reorganization as the turning point, the effective insulation of adat from colonial interference that permitted it to persist intact and unsullied until 1928, the historical evidence suggests that this was an additional

\footnotetext{
85 Jaspan, "Quest of New Law," pp. 264-65.

86 III 08, 1860 Political Report for Lampung.

87 Van Royen, "Verdwijning," p. 197.
} 
initiative in a continuum whereby the government's adat leaders poached on the prerogatives and responsibilities formerly the preserve of the penjimbangs. This encroachment on the latter's power and authority sharply limited their scope of action and undermined their position. It is true that people continued to submit their cases to the penjimbang and kept matters in the village when possible, and in this respect, various aspects of the adat system did persist. But the diminution of power, the rise of alternate sources of law and authority under the shadow of colonialism suggests that Van Royen's ideology of dualism, persistence amidst change, is a tenuous argument at best. The indigenous leaders continued to administer adat but no longer with reference to the overall organization of their community. They administered only in terms of selected elements in a dominated society.

The widespread unrest triggered by the Dutch attempt to revive and accord official recognition to this "true" adat system suggests that Van Royen underestimated the dynamic aspects of change unleashed in society by economic development and social progress. Society had changed dramatically as had the desires and needs of the people. The ossified adat system through which the Dutch hoped to further their aims had also changed dramatically during the sixty-year hiatus, both in substance and its ascribed role in the community. Even in the Resident's opinion, by the early 1920s, indigenous adat had degenerated into an elite ritual system that still held some sway in society but did not represent the potential basis of modern government. ${ }^{88}$ As the Lampungers complained, the reimposition of the marga system was like asking a man to wear the clothes he had worn as a youth. ${ }^{89}$

\section{Restoration of the Margas, Popular Protest, and Class Conflict}

To return to the development of the anti-marga campaign, the government's revival and embellishment of adat institutions was viewed by many people as an attempt to turn back time and place the people under an autocratic, exploitative system that primarily served the interests of the government and the elite at the expense of the people. ${ }^{90}$ Certainly, the issue of taxes was critical and material considerations weighed heavily, but the Comite Tani Lampung (CTL) focused attention on the complicity between the colonizers and the co-opted elite and the connections between the colonial government's manipulation of tradition and the injustice of the new taxes. ${ }^{91}$

It was the way the new taxes were introduced under the banner of tradition and the personal use of tax receipts by the traditional authorities that aroused defiance and sparked the contest over tradition. Perasaan admitted the colonial government's right to raise taxes and urged it to do so if necessary but excoriated the Dutch for trying to hide behind the figleaf of a distorted adat. There was a lack of faith in the new traditional leaders and ample evidence that they were enriching themselves rather than using the taxes to serve the needs of the community. Lampungers found it galling that their adat was being invoked to justify systematic injustice and that they had lost control of shaping adat to meet their needs. The upper class of official adat leaders and their colonial sponsors were seen as mutually re-

\footnotetext{
88 Breukink MVO 1923.

${ }^{89}$ Fadjar Soematera, May 3, 1930, no. 12.

90 See, for example, Fadjar Soematera, May 21, 1930, no. 11; June 21, 1930, no. 24.

91 See Perasaan May 7, 1929, no. 20; May 10, 1929, no. 21; June 6, 1929, no. 35; and September 29, 1929, no. 60. Perasaan, published twice a week in Teluk Betung between February and December 1929, was the voice of the CTL and carried extensive coverage on the anti-marga campaign until a boycott organized by pasirahstelsel leaders forced it out of business.
} 
sponsible for the rising level of exploitation; "the way of the marga is the way of the government." 92

The battle between Lampungers and the colonial government was fought over a seemingly well-intentioned effort to revive indigenous institutions precisely because it was "not just 'a tradition,' but a selective tradition: an intentionally selective version of a shaping past and a pre-shaped present, which is then powerfully operative in the process of social and cultural definition and identification." 93

That such a traditional system on a general level existed in the nineteenth century was not disputed; indeed the extent to which the new system reflected or distorted the "kernel of tradition" was a secondary concern. Foremost in the minds of the critics was whether the reconstituted marga system was appropriate and capable of dealing with the problems of twentieth-century Lampung in a manner that would serve the people. Tradition had, perhaps, always been used by the elite to serve their own interests but was granted legitimacy in the community only because the people believed that their own interests were also served. Adat had been in a constant state of flux because the needs of the community and the world in which adat was exercised were subject to ongoing change.

Yet, it was also feared that the shift in the locus of power, from the community to the state, had undermined the reciprocity that had formerly characterized relations between the people and their adat leaders, permitting the abuses documented in the archives and the vernacular press, Perasaan and Fadjar Soematera. ${ }^{94}$ Formerly, the adat leaders were restrained from pressing all their prerogatives by pragmatism, for their legitimacy lay in the people's good will, but with the backing of the state, there was no such need for restraint. Consequently, the onerous aspects of adat obligations became exaggerated, whereas the exercise of power in the vernacular of tradition never fully obscured class and colonial arrogance. ${ }^{95}$ The satraps were caught between the exigencies of a colonial state and popular discontent, unable to address either effectively. The elite's power to exploit had increased exponentially, but their legitimacy in the community and recognition of their prerogatives had atrophied irrevocably.

Precisely because the adat elite had for so long in the nineteenth and early twentieth centuries operated only within a limited sphere, the sudden reversal of their fortunes in 1928, with the restoration and exaggeration of prerogatives that had faded from customary practice, generated considerable resentment. Although legal scholars could trace these prerogatives to nineteenth-century adat practices faithfully recorded by their predecessors, the practices were archaic, no longer accepted as customary and legitimate, and, therefore, no longer viewed as adat. As Van Vollenhoven remarked about adat:

[The] future depends on its own usefulness, capacity for development and innate resilience. The fate of adat law does not lie in the hands of policy makers at Buitenzorg or the Hague, nor with the practitioners and scholars whose hearts have been won for the course of adat law, but with the Indonesian in their villages [reflecting] . . . the peoples own will to maintain, expand and rejuvenate their law. ${ }^{96}$

\footnotetext{
92 Perasaan, August 30, 1929, no. 53.

93 Williams, Marxism and Literature, p. 115.

94 This issue is well summarized in Perasaan, August 16, 1929, no. 49; and Fadjar Soematera, August 30, 1930 , no. 43.

${ }^{95}$ Fadjar Soematera, July 12, 1930, no. 30.

${ }^{96}$ As translated and cited in Holleman, Van Vollenhoven, p. 260.
} 
Unfortunately, the insights of Van Vollenhoven were not always put into practice by the colonial administrators on the spot whose appreciation for tradition was tempered by the need to promote effective administration.

The colonial officials believed that the ineffectiveness of the Western-based system of law and administration established in 1879 was related to the lack of continuity with tradition and sought a resolution to this problem by transforming the informal, indigenous adat institutions into apparatus for government administration. As Hooker suggests with regard to colonial Indonesia in general, "There was a conscious policy and effort to preserve traditional institutions and to identify obligation in terms of indigenous systems. At the same time the organization and administration of the state institutions could not treat the adat institutions and obligation systems on its own terms." 97 The exigencies of colonial rule required that the adat system assume competencies and powers it had never previously enjoyed. The difficulty lay in transforming adat mediators into efficient administrative bureaucrats who could still retain legitimacy among the people while serving the state. In granting powers of governance articulated within a traditional system that conferred none, the Dutch concocted an illusion that held little currency among the people.

Van Royen, the doyen of Lampung adat studies, conveys an extremely detailed and nuanced understanding of the adat system as it developed historically under Bantenese suzerainty and subsequent Dutch rule. He was aware of the lack of adat-based powers of governance exercised by marga heads, regional variations in the practice of adat, and the disruptive influence of colonial rule, and yet he was an ardent proponent of the 1928 marga system. To reiterate, this 1928 version of the marga system accorded extensive powers of governance to the marga heads, ignored regional variations, and was based on the assumption that indigenous adat had been unsullied by colonial influence. Van Royen, wearing his colonial administrator's hat, illustrates how powerful the ideology of dualism must have been as it engendered a cognitive dissonance that enabled him to reconcile or overlook the glaring inconsistencies.

The attempt to establish a satrapy on the ruins of the marga system generated popular discord with overtones of class conflict, although those writing in Perasaan and Fadjar Soematera were certainly more aware of this than the peasant community at large. At the CTL rallies, the small farmers spoke of inordinate taxation and levies by the pasirah while the leadership of the CTL focused on what they termed the "feudal" origins of the marga system and exploitation by the elite. ${ }^{98}$ By drawing attention to the trade in titles whereby wealthy people with no standing in adat could purchase titles that could propel them to lucrative positions in the Dutchified marga system, the CTL was focusing its attack on the upper class and their colonial mentors rather than strictly attacking tradition. In fact, possibly out of concern that they would alienate their following, the CTL argued that it did not oppose tradition per se but the manipulation thereof that militated against the interests of the people. The satrapies and, implicitly, the colonial overlords were assailed for placing the interests of the upper classes and their state sponsors above those of the people, using adat as a "tool of tyranny." Upon the departure of Resident Volmering in 1930, the official responsible for implementing the 1928 marga initiative, the local press noted how the wealthy were sad to see him go whereas the people never wanted him to return. ${ }^{99}$

97 Hooker, Adat Law, p. 62.

98 This protest movement is more fully discussed in Jeff Kingston, "The Comite Tani Lampung: Contesting Tradition' and the Genesis of Nationalism in Colonial Lampung" (Singapore: SEA Studies, forthcoming).

${ }^{99}$ Fadjar Soematera, March 29, 1930, no. 3. 
In studies about adat, there is a tendency to overlook the class nature of the system and how elites used it to maintain their wealth and status while ostensibly preserving social harmony and observing ritual obligations. The sacral and symbolic aspects of adat are very real, influencing the way people view their world and act in it. It is equally true, however, that adat does not serve all members of the community equally and excludes some altogether. Prior to the abolition of slavery in 1866, it was estimated that one-fifth of the community in Lampung were slaves who had almost no rights but considerable obligations under adat. Until redeemed, debt bondsmen were accorded the same standing as slaves. Abolition of slavery and debt bondage did not eliminate such practices performed under a different guise. At least through World War I, observers still noted that distinct lower classes existed that were excluded from adat ceremonies and relegated to the disadvantageous periphery of the adat community. ${ }^{100}$

The elaborate and expensive system of fines for transgressions against adat, levies on harvests, forest produce, and so forth, determined and collected by the adat elite, formed the economic basis of class differentiation. This is not to argue against the other levels of meaning at which adat operated and was identified in the community but serves as a reminder of the temporal realities upon which the often etherealized portrayal of adat is constructed; the spiritual and material are often intertwined. Through the adat system, the wealthy were able to "buy" status and, through this status, able to extract and accumulate resources from the less wealthy, untitled members of the community. Although such practices were relatively limited when the locus of legitimacy lay with the people, when it shifted to the state, reciprocal relations broke down and the previously blurred class distinctions grew increasingly rigid, accentuated by colonial intervention. As Schrieke commented regarding the relationship between the co-opted traditional elite and the colonial state, "Supported by the administration, of which they are the instruments, they begin to exhibit feudal tendencies in so far as the presence of an autocratic administration allows of it."101

When elucidating the different layers of meaning embedded in adat, it is useful to recall that adat was concerned with maintaining social harmony, but "Corsican vendettas" were not uncommon, just as adat maintained proper social organization while serving class exploitation. ${ }^{102}$

The anti-marga movement in Lampung initially gained support among the farmers owing to resentments stemming from rising tax levies. However, the CTL soon developed into more than a protest against rising taxes. The newly imposed "traditional" elite were the beneficiaries of the new marga taxes and augmented their relatively high incomes by imposing further unsanctioned taxes. It was clear that the new marga system involved a substantial transfer of wealth from the farmers to the elite pasirah. More than ever, the titled elite were able to mobilize a surplus from the adat community and, significantly, controlled access to land, the principal source of wealth.

The progressive journalists of Perasaan, who spearheaded the CTL, constantly drew attention to the depredations of pasirah exploitation, at times criticizing the pasirah far more harshly than the colonial administrators. The consequences of heightened class exploitation made possible by the new colonial initiatives galvanized support for the anti-marga cam-

\footnotetext{
100 Broersma, De Lampongsche Districten, pp. 73-76.

101 B.J.O. Schrieke, "Native Society in the Transformation Period," in Western Influence, ed. Schrieke, p. 240.

102 Dubois, "De Lampong's," p. 113. He describes the failures of adat to ensure social harmony and how conflict within the community was endemic, belying the visions of the golden past often conjured by those embracing adat studies.
} 
paign. Loose references to the exploitative feudal elite indicate that the CTL leadership did not have a sophisticated appreciation of class concepts, but they did draw attention to the manner in which the rigidified adat system had intensified the hardships of those without high adat status and enriched those who had been given power to manipulate and exaggerate traditional prerogatives.

Other studies on South Sumatra, although remaining attuned to the sacral elements of adat, shed light on the class connotations and consequences of colonial manipulation of tradition. In a compelling manner, Wuisman analyzes the consequences of nineteenth-century colonial manipulation of adat in terms of increased polarization of classes in Bengkulu. ${ }^{103}$ By undermining structures of reciprocity and weakening social relationships of interdependence within the local communities in the name of liberating the "natives" from the darkness of the primitive practices encountered, the Dutch promoted class rigidification and exploitation. They drove a wedge between the leaders and the led, fostering sharpened class differentiation and antagonism while closing the avenues of social mobility.

Similarly, in Lampung the anti-marga campaign featured an uneven contest between the Dutch and their satraps against the people, reflecting incipient class conflict between those whom official adat served and those whom it oppressed. The marga was shorn of its purpose in adat and transformed into yet another layer of bureaucracy, a relic that had been revived and manipulated to serve colonial and class interests.

Archival Note: Numbered references are based on the designations in the Inventaris Arsip Lampung. MVO refers to Memorie van Overgave followed by the name of the Resident who wrote it.

\author{
Key to Abbreviations: \\ BKI Bijdragen tot de Taal-, Land-en Volkenkunde van Nederlandsch-Indie \\ IG De Indische Gids \\ KS Koloniale Studien \\ KT Koloniaal Tijdschrift \\ MVO Memorie van Overgave (archival reports) \\ TBB Tijdschrift voor het Binnenlandsch Bestuur \\ TBG Tijdschrift voor Indische Taal-, Land en Volkenkunde published by the (Koninklijke) \\ Bataviaasch Genootschap van Kunsten en Wetenschappen. \\ TNI Tijdschrift voor Nederlandsch-Indie
}

103 Wuisman, Sociale Verandering, pp. 199-218. See also J. Kathirithamby-Wells, "A Survey of the Effects of British Influence on Indigenous Authority in Southwest Sumatra," BKI 129 (1973): 237-68. 
